\title{
Biogenic amines in raw and processed seafood
}

\section{Pierina Visciano* , Maria Schirone, Rosanna Tofalo and Giovanna Suzzi}

Department of Food Science, University of Teramo, Mosciano Sant'Angelo, Teramo, Italy

\section{Edited by:}

Sandra Torriani, Università degli Studi

di Verona, Italy

Reviewed by:

Antonio Valero, University of Cordoba, Spain

Alexandra Lianou, Aristotle University of Thessaloniki, Greece

${ }^{*}$ Correspondence:

Pierina Visciano, Department of Food Science, University of Teramo, 64023 Mosciano Sant'Angelo, Teramo, Italy. e-mail: pvisciano@unite.it
The presence of biogenic amines (BAs) in raw and processed seafood, associated with either time/temperature conditions or food technologies is discussed in the present paper from a safety and prevention point of view. In particular, storage temperature, handling practices, presence of microbial populations with decarboxylase activity and availability of free amino acids are considered the most important factors affecting the production of BAs in raw seafood. On the other hand, some food technological treatments such as salting, ripening, fermentation, or marination can increase the levels of BAs in processed seafood. The consumption of high amount of BAs, above all histamine, can result in food borne poisoning which is a worldwide problem. The European Regulation established as maximum limits for histamine, in fishery products from fish species associated with high histidine amounts, values ranging from 100 to $200 \mathrm{mg} / \mathrm{kg}$, while for products which have undergone enzyme maturation treatment in brine, the aforementioned limits rise to 200 and $400 \mathrm{mg} / \mathrm{kg}$. Preventive measures and emerging methods aiming at controlling the production of BAs are also reported for potential application in seafood industries.

Keywords: fish, histamine, bacteria, raw and processed seafood

\section{INTRODUCTION}

Seafood may harbor a number of biological, chemical, and physical hazards, the most prevalent of which are biogenic amines (BAs) and biotoxins (chemical), pathogenic bacteria and viruses (biological), and metal inclusion (physical). BAs are low molecular weight organic bases with biological activity that are formed in foods by microbial decarboxylation of the corresponding amino acids or by transamination of aldehydes and ketones by amino acid transaminases (Zhai et al., 2012). The most important BAs, histamine, tyramine, tryptamine, putrescine, and cadaverine, are formed from free amino acids namely histidine, tyrosine, tryptophane, ornithine and lysine, respectively. Spermidine and spermine arise from putrescine (Zarei et al., 2011). Putrescine, cadaverine, spermidine, and spermine have an aliphatic structure; histamine, and tryptamine have a heterocyclic structure and tyramine and phenylethylamine have an aromatic structure (Mohamed et al., 2009). The free amino acids either occur as such in foods or may be liberated through proteolysis. In addition to the availability of precursors (amino acids), BAs accumulation in foods requires the presence of microorganisms with amino acid decarboxylases and favorable conditions for their growth and decarboxylation activity (Zarei et al., 2011). Storage temperature is the most important factor contributing to BAs formation (Chong et al., 2011). Other parameters (i.e., $\mathrm{pH}$, water activity, $\mathrm{NaCl}$ concentration, additives) may influence the variation of microbiota composition and lead to the differences in BAs content (Suzzi and Gardini, 2003). In addition, modified atmosphere packaging and vacuum packaging represent popular preservation methods which may inhibit the growth and increase the lag phase of microorganisms with amino acid decarboxylase activity (Chong et al., 2011).

The toxicological level of BAs is very difficult to establish because it depends on individual characteristics and the presence of other amines. However, a maximum total BAs level of $750-900 \mathrm{mg} / \mathrm{kg}$ has been proposed (Ladero et al., 2010).

The microbiological complexity of seafood is linked to the specific as well as non-specific microbial contaminants originating from the natural environment or being acquired during processing. The wide range of environmental habitats (freshwater to saltwater, tropical waters to arctic waters, pelagic swimmers to bottom dwellers, and degree of pollution) and the variety of processing practices (iced fish products to canned products) are all important factors in determining the initial contamination of fish and fish products (Gram and Huss, 1996). The types of bacteria that are associated with histamine production are commonly present in the saltwater environment. They naturally exist on the gills, on external surfaces, and in the gut of live, saltwater fish, with no harm to the fish. Upon death, the defense mechanisms of the fish no longer inhibit bacterial growth in the muscle tissue, and histamine-forming bacteria may start to grow, resulting in the production of BAs [Food and Drug Administration (FDA), 2011]. Evisceration and removal of the gills may reduce, but not eliminate, the number of histamine-forming bacteria. Packing of the visceral cavity with ice may aid in chilling large fish in which internal muscle temperatures are not easily reduced. However, when done improperly, these steps may accelerate the process of histamine development in the edible portions of the fish by spreading the bacteria from the visceral cavity to the flesh of the fish. With some harvesting practices, such as long-lining and gillnetting, death may occur many hours before the fish is removed from the water. Under the worst conditions, histamine formation can already be under way before the fish is brought onboard the vessel. This condition can be further aggravated with certain tuna species that generate heat, resulting in internal temperatures that may exceed environmental temperatures and increasing the 
likelihood of conditions favorable to growth of enzyme-forming bacteria (FDA, 2011).

Some technological processes such as salting, ripening, fermentation or marination can increase the possibility of formation of BAs. A low pH (4.0-5.5), which can be achieved in salted anchovies, for instance, is favorable for enhanced amino acid decarboxylase activity (Pons-Sánchez-Cascado et al., 2005a). Moreover, important proteolysis is observed during ripening of salted anchovies, resulting in the liberation of peptides and free amino acids including histidine (Hernández-Herrero et al., 2002). The association of salted fish with histamine formation is probably due to the presence of halophilic or halotolerant microorganisms. For instance, Hernández-Herrero et al. (1999) reported that Staphylococcus epidermidis and Staphylococcus capitis, isolated from salted anchovies, showed a powerful histamine-forming activity, producing 1000 and $400 \mu \mathrm{g} / \mathrm{ml}$, respectively. They assumed that the presence of these bacteria could be the result of contamination of fish during capture and subsequent unhygienic handling. BAs can also be produced throughout the manufacturing process, as well as during storage of the end product if improper holding temperatures are employed (Periago et al., 2003; Yongsawatdigul et al., 2004).

\section{BACTERIA IN FISH}

The microorganisms of fish intended for human consumption depend on the environmental conditions of its natural habitat. In particular, the microflora of fish from temperate water consists primarily psychrotrophic Gram-negative bacteria belonging to the genera Pseudomonas, Moraxella, Acinetobacter, Shewanella, and Flavobacterium. Members of the Vibrionaceae (Vibrio and Photobacterium) and the Aeromonadaceae (Aeromonas spp.) families are also common aquatic bacteria and typical of the fish flora [Food and Agriculture Organization (FAO), 1995]. Although Gramnegative bacteria are the predominant microorganisms in fish, Gram-positive bacteria such as Bacillus, Micrococcus, Clostridium, Lactobacillus, and coryneforms can also be found at various levels. Aeromonas spp. are typical of freshwater fish, whereas a number of bacterial genera such as Vibrio, Photobacterium, and Shewanella require sodium for growth and are, thus, typical of marine waters (Gram et al., 1990). In polluted waters, high numbers of Enterobacteriaceae may be found. In clean temperate waters, these organisms disappear rapidly, but it has been shown that Escherichia coli and Salmonella can survive for very long periods in tropical waters, and that once introduced, they may become indigenous to the environment (Fujioka et al., 1988).

The composition of fish microbiota changes quite dramatically during spoilage. Shewanella putrefaciens and Pseudomonas aeruginosa have been identified as the prominent spoilage bacteria of fresh fish (Gram and Huss, 1996). At ambient temperature $\left(25^{\circ} \mathrm{C}\right)$, the microbiota at the point of spoilage is dominated by mesophilic Vibrionaceae and, particularly if the fish is caught in polluted waters, Enterobacteriaceae. Some Pseudomonas spp. are the specific spoilers of iced stored tropical freshwater fish and are also spoilers of marine tropical fish stored in ice (Gram and Huss, 1996). Many different bacterial species of the Enterobacteriaceae family are known to possess histidine decarboxylase activity and have the ability to produce histamine, including the species Morganella morganii, Klebsiella pneumoniae, Hafnia alvei,
Proteus vulgaris, Proteus mirabilis, Enterobacter aerogenes, Enterobacter cloacae, Serratia fonticola, Serratia liquefaciens, Raoultella (formerly Klebsiella) planticola, Raoultella ornithinolytica, Providencia stuartii, and Citrobacter freundii (Kim et al., 2003). In addition to the enteric bacteria, Clostridium spp., Vibrio alginolyticus, Acinetobacter lowffi, Plesiomonas shigelloides, Pseudomonas putida, Pseudomonas fluorescens, Aeromonas spp., and Photobacterium spp. have also been reported as histamine formers (Chen et al., 2010). Emborg et al. (2006) identified Morganella psychrotolerans, a strong histamine-former, as a novel psychrotolerant bacterium, whereas the study of Kanki et al. (2004) revealed that these low temperature-adapted bacteria could play a role in scombroid poisoning.

\section{BIOGENIC AMINES PRODUCTION IN RAW SEAFOOD}

Histamine levels in freshly caught fish are generally low, usually below $0.1 \mathrm{mg} / 100 \mathrm{~g}$ (Auerswald et al., 2006). At any time, exposure of certain fish to elevated temperatures after the catch and before consumption can cause formation of histamine from histidine by bacterial histidine decarboxylases. While most studies agree that histamine formation is negligible in fish stored at $0^{\circ} \mathrm{C}$ or below, data concerning storage conditions at higher temperatures are variable and do not allow for the establishment of standard procedures for avoiding potential negative effects of transport/storage conditions on fish safety (Rossano et al., 2006). However, fish is more likely to form BAs when decomposition occurs at harvest or in the first stages of handling on the fishing vessels, rather than later in the distribution chain (Staruszkiewicz et al., 2004).

The term "scombroid" is derived from the name of the family Scombridae which includes the fish species that were first implicated in histamine intoxication (i.e., tuna and mackerel). These species of fish share in common high levels of free histidine in their muscle tissues. It is known that other non-scombroid fish species are also implicated in scombroid poisoning, such as mahi-mahi (Coryphaena spp.), sardines (Sardinella spp.), pilchards (Sardina pilchardus), anchovies (Engraulis spp.), herring (Clupea spp.), marlin (Makaira spp.), bluefish (Pomatomus spp.), Western Australian salmon (Arripis truttaceus), sockeye salmon (Oncorhynchus nerka), amberjack (Seriola spp.), Cape yellowtail (Seriola lalandii), and swordfish (Xiphias gladius). With the exception of salmon and swordfish, most of these fish species are rich in free histidine (Hungerford, 2010). However, it has been found that histamine poisoning may not be caused to all the people consuming contaminated fish. Given that histamine-forming bacteria may be diversely distributed in fish, the diffusion of produced histamine may also vary widely in different parts of the animal. For instance, while $50 \mathrm{mg} / \mathrm{kg}$ of histamine may be found in one fish section, its level may exceed $500 \mathrm{mg} / \mathrm{kg}$ in another (FDA, 2011). Thus, even if the same histamine-containing fish is ingested, some consumers may be poisoned and some may not (Tao et al., 2002, 2009).

Histamine is produced in raw fish from the action of bacterial histidine decarboxylase following temperature/time abuse. Production of histamine is greater, however, at high abusive temperatures $\left(21.1^{\circ} \mathrm{C}\right.$ or higher) than at moderate abusive temperatures $\left(7.2^{\circ} \mathrm{C}\right)$, while its generation is particularly rapid at temperatures near $32.2^{\circ} \mathrm{C}$ (FDA, 2011). According to European Regulation fresh fishery products, thawed unprocessed fishery products, and 
cooked and chilled products from crustaceans and mollusks must be maintained at a temperature approaching that of melting ice (European Commission, 2004). Rapid chilling of scombrotoxinforming fish immediately after death is the most important element in any strategy for preventing the formation of histamine, especially for fish that is exposed to warm waters or air, and for tunas which generate heat in their tissues. Failure to chill onboard may permit bacteria and enzymes, including those that form histamine, to increase to high levels (FDA, 2011). Even if ice storage is recommended, temperature/time abuse conditions often occur in the fish merchandising chain. Delays in removing fish from the water after capture, such as those captured by a longline, may significantly limit the amount of time left for chilling and may allow some fish to heat up. Moreover, mishandling coupled with high temperature abuse are likely when handling fish and may significantly enhance histamine formation. The amount of post-harvest time at elevated temperatures (after proper chilling onboard the harvest vessel) to which a fish can be exposed (e.g., during processing, storage, and distribution) without adverse effects depends primarily on whether the fish was previously frozen (e.g., in the harvest vessel) or heat-processed sufficiently to destroy histamineforming bacteria (FDA, 2011). Rossano et al. (2006) studied the influence of storage temperature and time of freezing on histamine formation in anchovies, showing the ability of freezing to inhibit or slow down its formation.

Many scientists have studied the effects of storage temperatures on histamine formation in fish and their results have been very often ambiguous. This can be explained by the differences in the composition and the level of microorganisms in the fish. Histamine producing bacterial species and strains vary considerably in amounts of histamine formation, and the type of spoilage bacteria present depends on the aquatic environment. It has been reported that $M$. morganii, $K$. pneumoniae, and $P$. vulgaris are prolific histamine formers, producing $>1000 \mathrm{mg} / \mathrm{kg}$ in the culture broth (López-Sabater et al., 1996; Rawles et al., 1996; Kim et al., 2001). These species have rarely been detected in fresh fish, but have mostly been isolated from fish spoiled under controlled storage conditions, above $20^{\circ} \mathrm{C}$ (Ababouch et al., 1991; Kim et al., 2001). Bacteria occurring naturally in marine environments such as Photobacterium spp., Pseudomonas spp., Vibrio alginolyticus, and Aeromonas spp. have indeed been frequently isolated from fish stored at refrigeration temperature for extended periods (Middlebrooks et al., 1988; Morli et al., 1988). However they are weak histamine formers, producing $<500 \mathrm{mg} / \mathrm{kg}$ in the culture broth (Frank et al., 1985). Then, in raw fish histamine content is linked to the type of histamine-forming bacteria, the type of seafood, and temperature/time storage conditions (Table 1). Typically, boats fish overnight in a trip of up to $12 \mathrm{~h}$. Storage is at ambient temperature until unloaded at the processing plant, with the first-caught fish being already stored for up to $10 \mathrm{~h}$. Such a long period may cause histamine-producers to undergo nine doublings, an increase of 1000 times (three log scales) over the assumed initial level of $10 / \mathrm{g}$ or $\mathrm{cm}^{2}$, reaching a level of $10000 / \mathrm{cm}^{2}$ at fish surfaces or $10000 / \mathrm{g}$ in the gut $(\mathrm{FAO}, 2004)$.

In addition to their toxicological implications, BAs are related to fish spoilage, since they accumulate as a result of the proteolytic and amino acid decarboxylase activity of microorganisms

\begin{tabular}{|c|c|c|c|}
\hline Fish & Temperature/time & $\begin{array}{l}\text { Histamine } \\
(\mathrm{mg} / \mathrm{kg})\end{array}$ & Reference \\
\hline Pacific mackerel & $25^{\circ} \mathrm{C}$ for $48 \mathrm{~h}$ & 2830.0 & Kim et al. (2001) \\
\hline Yellowfin tuna & $22^{\circ} \mathrm{C}$ for $5 \mathrm{~d}$ & 4533.0 & Du et al. (2002) \\
\hline Albacore tuna & $25^{\circ} \mathrm{C}$ for $6 \mathrm{~d}$ & 671.0 & Kim et al. (2002a) \\
\hline Mackerel & $\begin{array}{l}25^{\circ} \mathrm{C} \text { for } 24 \mathrm{~h} \text { (inoc- } \\
\text { ulated with Mor- } \\
\text { ganella morganii) }\end{array}$ & 4610.0 & Kim et al. (2002b) \\
\hline Albacore & & 3430.0 & \\
\hline Mahi-mahi & & 3340.0 & \\
\hline Salmon & & 255.0 & \\
\hline Skipjack tuna & $21^{\circ} \mathrm{C}$ for $48 \mathrm{~h}$ & 1533.0 & Rossi et al. (2002) \\
\hline \multirow[t]{3}{*}{ Mackerel } & $32.2^{\circ} \mathrm{C}$ for $9 \mathrm{~h}$ & 28.0 & Shakila et al. (2003) \\
\hline & $32.2^{\circ} \mathrm{C}$ for $12 \mathrm{~h}$ & 50.0 & \\
\hline & $32.2^{\circ} \mathrm{C}$ for $16 \mathrm{~h}$ & 100.0 & \\
\hline Mahi-mahi & $26^{\circ} \mathrm{C}$ for $12 \mathrm{~h}$ & 50.0 & Staruszkiewicz et al. \\
\hline Skipjack tuna & $25^{\circ} \mathrm{C}$ for $10 \mathrm{~h}$ & 10.0 & $(2004)$ \\
\hline Yellowfin tuna & $25^{\circ} \mathrm{C}$ for $12 \mathrm{~h}$ & 10.0 & \\
\hline Yellowfin tuna & $20^{\circ} \mathrm{C}$ for $24 \mathrm{~h}$ & 111.4 & Guizani et al. (2005) \\
\hline Sailfish & $25^{\circ} \mathrm{C}$ for $24 \mathrm{~h}$ & 2240.0 & Tsai et al. (2005a) \\
\hline Milkfish & & 3990.0 & \\
\hline Anchovy & $25^{\circ} \mathrm{C}$ for $24 \mathrm{~h}$ & 1465.0 & Visciano et al. (2007) \\
\hline Pilchard & & 1106.0 & \\
\hline Mackerel & $25^{\circ} \mathrm{C}$ for $24 \mathrm{~h}$ & 2123.9 & Kim et al. (2009) \\
\hline Saury & & 1776.7 & \\
\hline Spanish mackerel & & 189.9 & \\
\hline Amberjack & & 36.6 & \\
\hline \multirow[t]{2}{*}{ Tuna fish } & $\begin{array}{l}25^{\circ} \mathrm{C} \text { for } 48 \mathrm{~h} \text { (inoc- } \\
\text { ulated with Mor- } \\
\text { ganella morganii) }\end{array}$ & $\begin{array}{l}2000.0- \\
4000.0\end{array}$ & Tao et al. (2009) \\
\hline & $\begin{array}{l}25^{\circ} \mathrm{C} \text { for } 48 \mathrm{~h} \text { (inoc- } \\
\text { ulated with Pho- } \\
\text { tobacterium phos- } \\
\text { phoreum) }\end{array}$ & $\begin{array}{l}1500.0- \\
1800.0\end{array}$ & \\
\hline
\end{tabular}

(Table 2). The use of more than a single BA (i.e., a BA index that consists of a combination of BAs) can be used as a quality indicator for fish freshness. Some examples are the sum of cadaverine and putrescine (Stede and Stockemer, 1981), the index of Mietz and Karmas (1981), which considers the increases in putrescine, cadaverine and histamine levels along with the corresponding decreases in spermidine and spermine, as well as the index described by Veciana-Nogués et al. (1997a) for tuna, which includes putrescine, cadaverine, histamine, and tyramine. In their study, Baixas-Nogueras et al. (2005) used these indexes for the freshness evaluation of iced Mediterranean hake (Merluccius merluccius) in the chilling conditions as applied in the merchandising chain. Putrescine and cadaverine were the main amines accumulated, whereas histamine and tyramine were less abundant. Cadaverine was the amine best correlated with S. putrefaciens, the specific spoilage organism, while putrescine showed the most satisfactory correlation with the genus Pseudomonas. According to the 
obtained results, the authors proposed a BAs index limit of acceptability in a range of $15-20 \mu \mathrm{g} / \mathrm{g}$. The study of Veciana-Nogués et al. (1997a), indeed, considered BAs as hygienic quality indicators in tuna (Thunnus thynnus), a fish belonging to the Scombridae family and therefore, with high levels of free histidine in its muscle. So, the value of $50 \mu \mathrm{g} / \mathrm{g}$ for the sum of histamine, tyramine, putrescine, and cadaverine, which was not exceeded in samples stored at $0^{\circ} \mathrm{C}$ before organoleptic rejection, was proposed as a guiding limit value for tuna acceptance.

\section{BIOGENIC AMINES IN PROCESSED SEAFOOD}

BAs formation is possible during processes such as brining, salting, smoking, drying, fermenting, and pickling until the product is fully shelf-stable (Table 3). Refrigeration can be used to inhibit histamine formation during these processes (FDA, 2011). Samples of fermented fish products (fish sauce, fish paste, and shrimp paste) were analyzed for histamine content (Tsai et al., 2006), which was 394,263 , and $382 \mathrm{mg} / \mathrm{kg}$, respectively. Three fish sauces, two fish pastes, and two shrimp paste products contained greater than $500 \mathrm{mg} / \mathrm{kg}$ of histamine. Moreover $7.4 \%$ of the tested samples contained $>1000 \mathrm{mg} / \mathrm{kg}$. The average content of various BAs in tested samples was less than $90 \mathrm{mg} / \mathrm{kg}$. The fish paste Rihaakuru, which is an important condiment in the Maldives, could contain high concentrations of BAs, due to raw tuna, from which the product is made from, being subjected to temperature abuse. Twenty-eight samples of Rihaakuru (Naila et al., 2011), were analyzed for some BAs; in particular, histamine was detected at the highest concentration $(5487 \mathrm{mg} / \mathrm{kg}$ ). Tryptamine was not detected in most of the samples (only three samples contained $<5 \mathrm{mg} / \mathrm{kg}$ ) and phenylethylamine only occurred at low levels $(<25 \mathrm{mg} / \mathrm{kg})$. The authors supposed that the histamine found in Rihaakuru samples was most likely to have originated from Gram-negative bacteria growing in the fish before processing or within the fish during the early steps of manufacture. There are other processed seafood which have been investigated for BAs content. In southern China, three fish products are widely consumed: salted and fermented fish, canned fish, and packaged fish. Zhai et al. (2012) examined 49 fish products from the China market. The maximum total BAs content of lightly cured horse mackerel was $484.42 \mathrm{mg} / \mathrm{kg}$ compared to $167.86 \mathrm{mg} / \mathrm{kg}$ or less for the other salted and fermented fish products. In the Spanish mackerel sample, histamine was detected within the range of $15.74-28.70 \mathrm{mg} / \mathrm{kg}$, whereas the maximum histamine level was $26.95 \mathrm{mg} / \mathrm{kg}$ in canned anchovies, $22.38 \mathrm{mg} / \mathrm{kg}$ in canned sardines and less than $10 \mathrm{mg} / \mathrm{kg}$ in all other canned samples tested (Zhai et al., 2012). Mah et al. (2002) found high levels of histamine $(155-579 \mathrm{mg} / \mathrm{kg})$ in fermented fish products made from anchovies, whereas Huang et al. (2010) reported large amounts of histamine in dried fish products (63.1-479.0 mg/kg).

Ripened, semi-preserved anchovies are prepared from fish of the Engraulis encrasicholus species, and are a common tradition in some Mediterranean countries. Pons-Sánchez-Cascado et al. (2005a) studied BAs in salt-ripened anchovies reporting that tyramine was the most abundant amine, reaching values up to $90 \mathrm{mg} / \mathrm{kg}$, whereas histamine did not exceed $20 \mathrm{mg} / \mathrm{kg}$. Then, the same authors analyzed samples of vinegar-marinated anchovies and reported higher values for tyramine than histamine (7.81 and $0.54 \mathrm{mg} / \mathrm{kg}$, respectively) in 14 days of refrigerated storage (Pons-Sánchez-Cascado et al., 2005b).

The applicability of lactic acid bacteria (LAB) in fermenting whole fish has been demonstrated. The fermentation process for fish may fulfill the conditions required for abundant formation of BAs, i.e., availability of free amino acids, the presence of decarboxylase-positive microorganisms and conditions allowing bacterial growth, decarboxylase synthesis, and decarboxylase activity (Petäjä et al., 2000). Some fish sauce products, particularly those made from sardine and mackerel, often contain large quantities of histamine, about $1000 \mathrm{mg} / \mathrm{l}$ or greater (Tsai et al., 2006; Kuda and Miyawaki, 2010), as a result of the histidine decarboxylase of Tetragenococcus spp., a halophilic lactic acid bacterium. However, most studies (Thapa et al., 2006; Muñoz-Atienza et al., 2011) showed that in fermented fish products LAB produced no histamine or other BAs. Kuda et al. (2012) reported the possibility of regulation of histamine accumulation in salted and fermented fish products by the addition of halophilic LAB, like a starter culture, isolated from nukazuke (salted and fermented fish with rice bran). In a total of 200 isolates from nukazuke fish, 13 strains produced histamine in histidine containing broth $(0.5 \%)$ at levels more than $200 \mu \mathrm{g} / \mathrm{ml}$, whereas 130 isolates produced no histamine. Furthermore, 22 of the tested strains appeared to suppress histamine production (Kuda et al., 2012).

\section{HISTAMINE FORMATION AND POISONING}

Histamine poisoning occurs throughout the world and is perhaps the most common form of toxicity caused by the ingestion of fish (Table 4). However, reliable statistics about its incidence do not exist because poisoning incidents are often unreported due to mild symptoms, lack of adequate reporting systems, or misdiagnoses by medical personnel of histamine poisoning as a food allergy (FAO, 2004).

Many BAs have been found in fish, but only histamine, cadaverine, and putrescine have been identified as significant concerns with regard to fish safety and quality (Al Bulushi et al., 2009). Despite the widely accepted association between histamine and scombroid food poisoning, histamine alone appears to be insufficient to cause toxicity, and putrescine and cadaverine have been suggested to potentiate its toxic activity by inhibiting the intestinal histamine-metabolizing enzymes, diamine oxidase and histamine N-methyltranferase (Stratton et al., 1991). The onset of scombroid poisoning is typically from $10 \mathrm{~min}$ to $1 \mathrm{~h}$ following consumption of fish and can last from $12 \mathrm{~h}$ to a few days. The symptoms are variable and include peppery or metallic taste, oral numbness, headache, dizziness, palpitations, rapid and weak pulse, drop in blood pressure, difficulty in swallowing, and thirst. Also noteworthy are allergy-like symptoms such as hives, rash, flushing, and facial swelling (Hungerford, 2010). Symptoms involving the central nervous system such as anxiety are less frequently observed. Less specific symptoms such as nausea, vomiting, abdominal cramps, and diarrhea are also experienced (Gilbert et al., 1980). Serious cardiac and respiratory complications may be caused in individuals with preexisting conditions (Ascione et al., 1997). In a few rare cases hospitalization, including treatment for anaphylactic shock, has been required (Sanchez-Guerrero et al., 1997). 
Table 2 | Levels (mean value, $\mathrm{mg} / \mathrm{kg}$ ) of BAs in raw seafood.

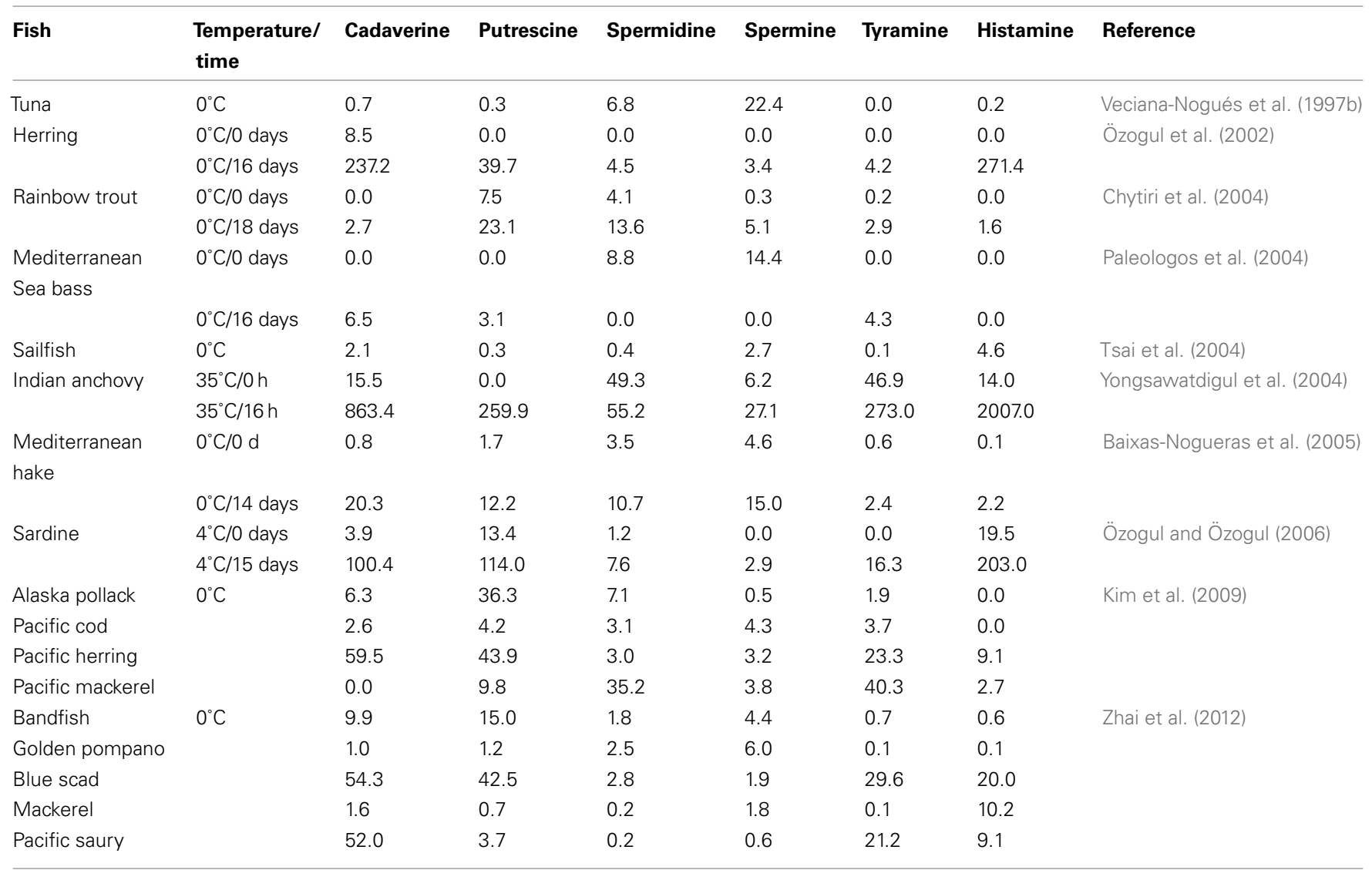

Table 3 | Levels (mean value, $\mathbf{m g} / \mathbf{k g}$ ) of BAs in processed seafood.

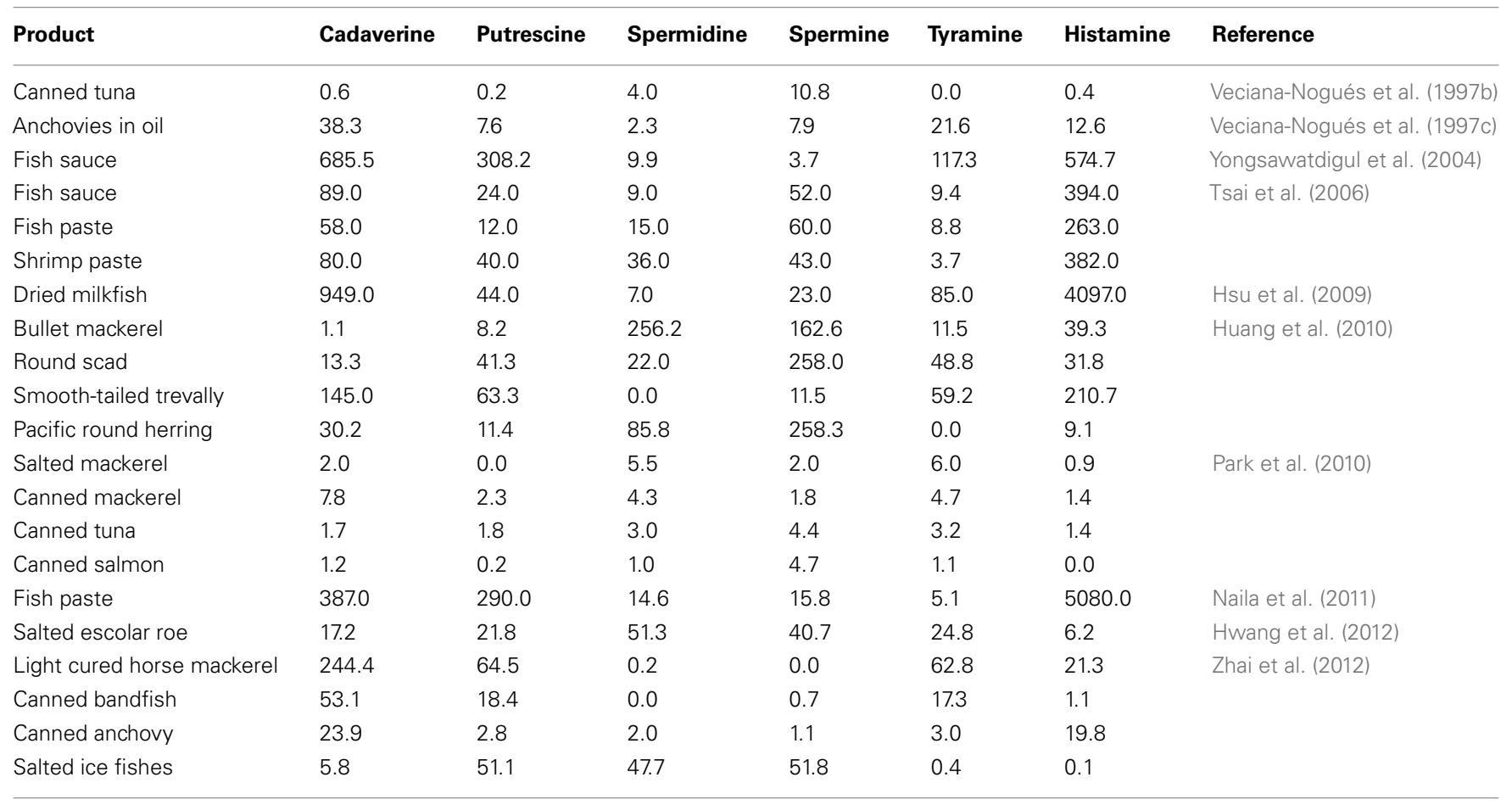


Table 4 | Outbreaks of scombroid poisoning: source, geographical location, period, and number of involved cases.

\begin{tabular}{|c|c|c|c|c|}
\hline Source & Location & Period & No. cases & Reference \\
\hline Canned tuna & USA & 1973 & 254 & Merson et al. (1974) \\
\hline Mackerel, tuna, anchovies, sardines, marlin & Japan & $1970-1980$ & 4122 & Taylor (1986) \\
\hline Dried horse mackerel & Japan & 1973 & 2656 & Taylor (1986) \\
\hline Tuna, mackerel & Italy & 1979 & 250 & Molinari et al. (1989) \\
\hline Yellowtail & South Africa & 1992 & 22 & Müller et al. (1992) \\
\hline \multirow[t]{3}{*}{ Tuna (fresh/frozen, canned), mackerel } & United Kingdom & 1987-1996 & 243 (sporadic) & Scoging (1998) \\
\hline & & & 105 (general) & \\
\hline & & & 56 (family) & \\
\hline Fish & USA & 1993-1997 & 297 & Olsen et al. (2000) \\
\hline Yellowtail & South Africa & 2004 & 19 & Anonymous (2004) \\
\hline Canned mackerel & Taiwan & 2001 & 3 & Tsai et al. (2005b) \\
\hline Tuna & South Africa & 2004 & 1 & Auerswald et al. (2006) \\
\hline Fish & USA & 1998-2002 & 463 & Lynch et al. (2006) \\
\hline Swordfish & Taiwan & 2004 & 43 & Chang et al. (2008) \\
\hline Dried milk fish & Taiwan & 2006 & 3 & Huang et al. (2010) \\
\hline Fried fish cubes & Taiwan & 2007 & 347 & Chen et al. (2010) \\
\hline
\end{tabular}

According to the FDA guidelines (FDA, 2011), the toxicity and defect action levels of histamine, established for tuna, mahi-mahi, and related fish, are the $50 \mathrm{mg} / 100 \mathrm{~g}$ and $5 \mathrm{mg} / 100 \mathrm{~g}$, respectively; the term "defect action level" refers to the level of histamine naturally or inevitably occurring in foods without, however, presenting a considerable hazard for humans. According to the EU Regulation No 2073/2005 nine samples should be taken from each batch of fish species of the following families: Scombridae, Clupeidae, Engraulidae, Coryfenidae, Pomatomidae, Scombresosidae. These samples must fulfill the following requirements:

Mean value of all samples must not exceed $10 \mathrm{mg} / 100 \mathrm{~g}$; Two samples may be $>10 \mathrm{mg} / 100$ but $<20 \mathrm{mg} / 100 \mathrm{~g}$;

No sample may exceed $20 \mathrm{mg} / 100 \mathrm{~g}$.

However, fish belonging to these families that have undergone enzyme ripening in brine may have higher histamine levels, but not more than twice the above values.

\section{ANALYTICAL METHODS FOR BAs DETECTION}

The number and variety of methods developed for laboratory histamine testing of fish and fishery products is impressive. In contrast to many of the other more potent seafood toxins, the relatively high action levels established for histamine in fish allow for its detection by a variety of different approaches ranging from simple and inexpensive thin layer chromatography (TLC) procedures to resource-intensive and more powerful liquid chromatographymass spectrometry (LC-MS) methods (Hungerford, 2010). Most of the histamine separation methods applied in fish use reversedphase high performance liquid chromatography (HPLC) with detection schemes based on pre-column derivatization (Mietz and Karmas, 1978; Hui and Taylor, 1983; Malle et al., 1996) or post-column derivatization (Glória et al., 1999; Brillantes and Samosorn, 2001) to produce fluorescent products or strong chromophores, but direct UV detection of histamine imidazole ring has also been applied (Shakila et al., 2001; Cinquina et al., 2004b).
Other popular separation-based methods include ion chromatography (Cinquina et al., 2004a), capillary electrophoresis (Zhang and Sun, 2004), paper electrophoresis (Sato et al., 2002, 2006), TLC (Bajc and Gacnik, 2009), and gas chromatography-mass spectrometry (Marks and Anderson, 2006). In addition, there is a need for methods well suited to high-speed screening. The most rapid method for detecting histamine is based on flow injection analysis (FIA) and is capable of screening 60 sample extracts/hour (Hungerford et al., 1990). Enzymatic methods are attractive for their selectivity and flow injection has been used in combination with enzyme electrodes for easy automation (Watanabe et al., 2007). Many other commercial test kits are available, based on selective antibodies (Lehane and Olley, 2000; Köse et al., 2009). Commercial test kits based on immunoassay methods for histamine analyses became popular because of their user friendliness and reduced time requirements compared to those of traditional analytical techniques. Recently many authors (Köse et al., 2011; Tahmouzi et al., 2011; Tao et al., 2011; Hungerford and Wu, 2012) report different methods for rapid determination of histamine in fish.

\section{CONTROL MEASURES}

The FDA has issued industry guidelines aiming at establishing procedures for the safe processing and importing of fish and fishery products based on the hazard analysis and critical control points (HACCP) approach (FDA, 2011). According to the most recent HACCP guidelines for the control of histamine production, a core temperature of $4.4^{\circ} \mathrm{C}$ or less should be achieved and maintained throughout handling, processing, and distribution of potentially hazardous fish. The primary goal of these guidelines is the growth inhibition of spoilage bacteria capable of producing histamine through proper handling and chilling of fish (FDA, 2011). In order to achieve this objective, all boats should ice fish immediately after landing aboard the vessel so that the temperature at sites of microbiological concern is reduced at levels capable of controlling the growth of histamine-producing bacteria. Moreover, an ice-plant 
could be built and ice made available at reasonable cost. Other spaces could also be modified so that the boats could be capable of carrying up to $100 \mathrm{~kg}$ of ice (FAO, 2004). It must be highlighted, however, that the time required to lower the internal temperature of fish after capture depends on a number of factors, including: (i) the harvest method; (ii) the size of the fish; (iii) the chilling method. Once chilled, the scombrotoxin-forming fish should be maintained as close as possible to the freezing point (or held frozen) until it is consumed (FDA, 2011).

At the processing plant, fish is gilled and gutted, then stored in ice until packed for air transport to the consumer country. Histamine decarboxylase activity could lead to a 10 -fold increase in histamine during processing, air freight and marketing. The preventive measures for this step include controlling refrigeration temperature in the plant or performing proper icing during storage of raw material, in-process product as well as finished product (FAO, 2004). During processing of fish (butchering, cleaning, brining, salting, smoking, drying, fermenting, pickling, mixing, stuffing, packing, labeling, and staging), it is recommended that it is not exposed to ambient temperatures above $4.4^{\circ} \mathrm{C}$ for more than $12 \mathrm{~h}$ cumulatively, if it has been previously frozen or heatprocessed sufficiently to destroy histamine-forming bacteria, or for more than $4 \mathrm{~h}$ in the other case (FDA, 2011). Given the heat-stable nature of histamine, the intended use of the product is not likely to affect the significance of this hazard. Recontamination of seafood with enzyme-forming bacteria in conjunction with temperature abuse may also allow for histamine formation following cooking. Thus, a conscientious sanitation program during seafood processing is of vital importance in order for recontamination events to be avoided.

Many recent studies proposed a new approach based on the employment of microorganisms or substances (additives, spices, disinfectants) able to inhibit histamine-forming bacteria. Mah and Hwang (2009a) studied the effects of food additives on BAs-producing strains of Bacillus licheniformis isolated from Myeolchi-jeot, with the greatest inhibitory effect being observed for glycine. The same product (Myeolchi-jeot) was ripened with the addition of a starter culture of Staphylococcus xylosus, which

\section{REFERENCES}

Ababouch, L., Afilal, M. E., Rhafiri, S., and Busta, F. F. (1991). Identification of histamine-producing bacteria isolated from sardine (Sardina pilchardus) stored in ice and at ambient temperature $\left(25^{\circ} \mathrm{C}\right)$. Food Microbiol. 8, 127-136.

Al Bulushi, I., Poole, S., Deeth, H. C., and Dykes, G. A. (2009). Biogenic amines in fish: roles in intoxication, spoilage, and nitrosamine formation - a review. Crit. Rev. Food Sci. Nutr. 49, 369-377.

Anonymous. (2004). The CapeTowner, 26 February.

Ascione, A., Barresi, L. S., Sarullo, F. M., and De Silvestre, G. (1997). Two cases of "scombroid syndrome" with severe cardiovascular compromise. Cardiologia 42, 1285-1288.
Auerswald, L., Morren, C., and Lopata, A. L. (2006). Histamine levels in seventeen species of fresh and processed South African seafood. Food Chem. 98, 231-239.

Baixas-Nogueras, S., Bover-Cid, S., Veciana-Nogués, M. T., MarinéFont, A., and Vidal-Carou, M. C. (2005). Biogenic amines index for freshness evaluation in iced mediterranean hake (Merluccius merluccius). J. Food Prot. 68, 2433-2438.

Bajc, Z., and Gacnik, K. S. (2009). Densitometric TLC analysis of histamine in fish and fishery products. J. Planar Chromatogr. 22, 15-17.

Brillantes, S., and Samosorn, W. (2001). Determination of histamine in fish sauce from Thailand using a solid phase extraction and high-performance liquid

was shown to be capable of degrading histamine and tyramine (Mah and Hwang, 2009b), while the use of spices, in particular garlic, also showed an inhibitory effect (Mah et al., 2009). The development of post-harvest treatments for reducing histamineforming bacteria in fish upon harvest is an important intervention strategy to prevent histamine formation in fish and control scombroid poisoning. Phuvasate and Su (2010) investigated the efficacy of treatments with electrolyzed oxidizing (EO) water and EO ice, containing $100 \mathrm{ppm}$ chlorine. According to these researchers, soaking of fish (salmon) in EO water reduced Enterobacter aerogenes and Morganella morganii by 1.3 and $2.2 \mathrm{log} \mathrm{CFU} / \mathrm{cm}^{2}$ respectively, while soaking yellowfin tuna in EO ice reduced the same microorganisms by 2.4 and $3.5 \mathrm{log} \mathrm{CFU} / \mathrm{cm}^{2}$, respectively. Moreover, emerging methods potentially applied as control measures include the addition of starter cultures that degrade histamine, the application of hydrostatic pressure, irradiation, and packaging (Naila et al., 2010).

\section{CONCLUSION}

Seafood is susceptible to contamination by BAs-producing microorganisms at different points of the food chain. High levels of BAs can be prevented through the application of good hygiene practices and proper temperatures during handling, delivery and storage. Although BAs formation is the result of bacterial growth, the presence of these undesirable compounds, especially histamine, is not always noticed by consumers. In fact, while a fish with obvious spoilage will most likely not be consumed, a fish with a good appearance and no detectable spoilage odors may be consumed even if it contains a high histamine level. Thus, the application of appropriate control measures is fundamental for assuring seafood safety and such a responsibility is shared among the seafood catchers, processors, distributors, retailers, and merchants.

\section{ACKNOWLEDGMENTS}

This research line has received funding from Cassa di Risparmio di Teramo (Rapid methods to determine and quantify tyramine content in dairy products of Abruzzo region).

chromatography. Fish. Sci. 67 1163-1168

Chang, S. C., Kung, H. F., Chen, H. C., Lin, C. S., and Tsai, Y. H. (2008). Determination of histamine and bacterial isolation in swordfish fillets (Xiphias gladius) implicated in a food borne poisoning. Food Control 19, 16-21.

Chen, H. W., Huang, Y. R., Hsu, H. H., Chen, W. C., Lin, C. M., and Tsai, Y. H. (2010). Determination of histamine and biogenic amines in fish cubes (Tetrapturus angustirostris) implicated in a food-borne poisoning. Food Control 21, 13-18.

Chong, C. Y., Abu Bakar, F., Russly, A. R., Jamilah, B., and Mahyudin, N. A. (2011). The effects of food processing on biogenic amines formation. Int. Food Res. J. 18, 867-876.
Chytiri, S., Paleologos, E., Savvaidis, I., and Kontominas, M. G. (2004). Relation of biogenic amines with microbial and sensory changes of whole and filleted freshwater rainbow trout (Onchorynchus mykiss) stored in ice. J. Food Prot. 67, 960-965.

Cinquina, A. L., Calí, A., Longo, F., DeSantis, L., Severoni, A., and Aballe, F. (2004a). Determination of biogenic amines in fish tissues by ionexchange chromatography with conductivity detection. J. Chromatogr. 1032, 73-77.

Cinquina, A. L., Longo, F., Calí, A., DeSantis, L., Baccelliere, R., and Cozzani, R. (2004b). Validation and comparison of analytical methods for the determination of histamine in tuna fish samples. J. Chromatogr. 1032, 79-85. 
Du, W. X., Lin, C. M., Phu, A. T., Cornell, J. A., Marshall, M. R., and Wei, C. I. (2002). Development of biogenic amines in yellowfin tuna (Thunnus albacares): effect of storage and correlation with decarboxylase-positive bacterial flora. J. Food Sci. 67, 292-301.

Emborg, J., Dalgaard, P., and Ahrens, P. (2006). Morganella psychrotolerans nov., a histamine producing bacterium isolated from various seafoods. Int. J. Syst. Evol. Microbiol. 56, 2473-2479.

European Commission. (2004). European Commission (EC) No 853/2004 of 29 April 2004 laying down specific hygiene rules for food of animal origin. Official Journal of the European Union, 226, 22-82. L139 of 30 April 2004.

European Commission. (2005). European Commission (EC) No 2073/2005 of 15 November 2005 on microbiological criteria for foodstuffs. Official Journal of the European Union, 338, 1-26. L338 of 22 December 2005.

Food and Agriculture Organization (FAO). (1995). Quality and Quality Changes in Fresh Fish. FAO Fisheries Technical Paper 348, Rome: Corporate Document Repository, Fisheries and Aquaculture Department.

Food and Agriculture Organization (FAO). (2004). Application of risk assessment in the fish industry. FAO Fisheries Technical Paper 442. Rome: Corporate Document Repository, Fisheries and Aquaculture Department.

Food and Drug Administration (FDA). (2011). Fish and Fishery Products Hazards and Controls Guidance, 4th Edn. Washington, DC: Department of Health and Human Services, Food and Drug Administration, Center for Food Safety and Applied Nutrition.

Frank, H. A., Baranowski, J. D., Chongsiriwatana, M., Brust, P. A., and Premaratne, R. J. (1985). Identification and decarboxylase activities of bacteria isolated from decomposed mahi-mahi (Coryphaena hippurus) after incubation at 0 and 32 . Int. J. Food Microbiol. 2, 331-340.

Fujioka, R. S., Tenno, K., and Kansako, S. (1988). Naturally occurring fecal coliforms and fecal Streptococci in Hawaii's freshwater streams. Toxic. Assess. 3, 613-630.

Gilbert, R. J., Hobbs, G., Murray, C. K., Cruickshank, J. G., and Young, S. E. J. (1980). Scombrotoxic fish poisoning: features of the first 50 incidents to be reported in Britain
(1976-1979). Br. Med. J. 281, 70-73. Glória, M. B. A., Daeschel, M. A., Craven, C., Hilderbrand, K. S. Jr. (1999). Histamine and other biogenic amines in Albacore tuna. J. Aquatic Food Prod. Technol. 8, 55-69. Gram, L., and Huss, H. H. (1996). Microbiological spoilage of fish and fish products. Int. J. Food Microbiol. 33, 121-137.

Gram, L., Wedell-Neergaard, C., and Huss, H. H. (1990). The bacteriology of spoiling lake Victorian Nile perch (Lates niloticus). Int. J. Food Microbiol. 10, 303-316.

Guizani, N., Al-Busaidy, M. A., AlBelushi, I. M., Mothershaw, A., and Rahman, M. S. (2005). The effect of storage temperature on histamine production and the freshness of yellowfin tuna (Thunnus albacares). Food Res. Int. 38, 215-222.

Hernández-Herrero, M. M., RoigSagués, A. X., Lopez-Sabater, E. I., Rodríguez-Jerez, J. J., and MoraVentura, M. T. (2002). Influence of raw fish quality on some physicochemical and microbial characteristics as related to ripening of salted anchovies (Engraulis encrasicholus L). Food Chem. Toxicol. 67, 2631-2640.

Hernández-Herrero, M. M., RoigSagués, A. X., Rodríguez-Jerez, J. J., and Mora-Ventura, M. T. (1999). Halotolerant and halophilic histamine-forming bacteria isolated during the ripening of salted anchovies. J. Food Prot. 62, 509-514.

Hsu, H. H., Chuang, T. C., Lin, H. C., Huang, Y. R., Lin, C. M., Kung, H. F., and Tsai, Y. H. (2009). Histamine content and histamine-forming bacteria in dried milkfish (Chanos chanos) products. Food Chem. 114, 933-938.

Huang, Y. R., Liu, K. J., Hsieh, H. S., Hsieh, C. H., Hwang, D. F., and Tsai, Y. H. (2010). Histamine level and histamine-forming bacteria in dried fish products sold in Penghu Island of Taiwan. Food Control 21, 1234-1239.

Hui, J. Y., and Taylor, S. L. (1983). High pressure liquid chromatographic determination of putrefactive amines in foods. J. AOAC Int. $66,853-857$.

Hungerford, J., and Wu, W. H. (2012). Comparison study of three rapid test kits for histamine in fish: biooscientific maxsignal enzymatic assay, neogen veratox ELISA, and the neogen reveal histamine screening test. Food Control 25, 448-457.

Hungerford, J. M. (2010). Scombroid poisoning: a review. Toxicon 56, 231-243.
Hungerford, J. M., Walker, K. D., Wekell, M. M., and La Rose, J. E. (1990). Selective determination of histamine by flow injection analysis. Anal. Chem. 62, 1971-1976.

Hwang, C. C., Lin, C. M., Huang, C. Y., Huang, Y. L., Kang, F. C., Hwang, D. F., and Tsai, Y. H. (2012). Chemical characterisation, biogenic amines contents, and identification of fish species in cod and escolar steaks, and salted escolar roe products. Food Control 25, 415-420.

Kanki, M., Yoda, T., Ishibashi, M., and Tsukamoto, T. (2004). Photobacterium phosphoreum caused a histamine fish poisoning incident. Int. J. Food Microbiol. 92, 79-87.

Kim, M. K., Mah, J. H., and Hwang, H. J. (2009). Biogenic amine formation and bacterial contribution in fish, squid and shellfish. Food Chem. 116, 87-95.

Kim, S. H., Barros-Velazquez, J., BenGigirey, B., Eun, J. B., Jun, S. H., Wei, C., and An, H. (2003). Identification of the main bacteria contributing to histamine formation in seafood to ensure product safety. Food Sci. Biotechnol. 12, 451-460.

Kim, S. H., Field, K. G., Chang, D. S., Wei, C. I., and An, H. (2001). Identification of bacteria crucial to histamine accumulation in Pacific mackerel during storage. J. Food Prot. 64, 1556-1564.

Kim, S. H., Price, R. J., Morrissey, M. T. Field, K. G., Wei, C. I., and An, H. (2002a). Occurrence of histamineforming bacteria in albacore and histamine accumulation in muscle at ambient temperature. J. Food Sci. 67, 1515-1521.

Kim, S. H., Price, R. J., Morrissey, M. T., Field, K. G., Wei, C. I., and An, H. (2002b). Histamine production by Morganella morganii in mackerel, albacore, mahi-mahi, and salmon at various storage temperatures. J. Food Sci. 67, 1522-1528.

Köse, S., Kaklikkaya, N., Koral, S., Tufan, B., Buruk, C. K., and Aydin, F. (2011). Commercial test kits and the determination of histamine in traditional (ethnic) fish productsevaluation against an EU accepted HPLC method. Food Chem. 125, 1490-1497.

Köse, S., Koral, S., Kaklikkaya, N., Buruk, C. K., Tufan, B., Aydin, F., and Karaibrahimoglu, Y. (2009). Investigating suitability of commercial histamine test kits for monitoring histamine in traditional fish products. Presented at IFT Conference, Aquatic Food Products Division, 5-10 June 2009, Anaheim, CA.
Kuda, T., Izawa, Y., Ishii, S., Takahashi, H., Torido, Y., and Kimura, B. (2012). Suppressive effect of Tetragenococcus halophilus, isolated from fishnukazuke, on histamine accumulation in salted and fermented fish. Food Chem. 130, 569-574.

Kuda, T., and Miyawaki, M. (2010). Reduction of histamine in fish sauces by rice bran nuka. Food Control 21, 1322-1326.

Ladero, V., Calles-Enriquez, M., Fernandez, M., and Alvarez, M. A. (2010). Toxicological effects of dietary biogenic amines. Curr. Nutr. Food Sci. 6, 145-156.

Lehane, L., and Olley, J. (2000). Histamine fish poisoning revisited. Int. J. Food Microbiol. 58, 1-37.

López-Sabater, E. I., Rodríguez-Jerez, J. J., Hernández-Herrero, M., Roig-Sagués, A. X., and MoraVentura, M. T. (1996). Sensory quality and histamine-forming during controlled decomposition of tuna (Thunnus thynnus). J. Food Prot. 59, 167-174.

Lynch, M., Painter, J., Woodruff, R., and Braden, C. (2006). Surveillance for foodborne-disease outbreaks, United States, 1998-2002. MMWR CDC Surveill. Summ. 55, $1-34$.

Mah, J. H., Han, H. K., Oh, Y. J., Kim, M. G., and Hwang, H. J. (2002). Biogenic amines in Jeotkals, Korean salted and fermented fish products. Food Chem. 79, 239-243.

Mah, J. H., and Hwang, H. J. (2009a). Effects of food additives on biogenic amine formation in MyeolchiJeot, a salted and fermented anchovy (Engraulis japonicus). Food Chem. 114, 168-173.

Mah, J. H., and Hwang, H. J. (2009b). Inhibition of biogenic amine formation in a salted and fermented anchovy by Staphylococcus xylosus as a protective culture. Food Control 20, 796-801.

Mah, J. H., Kim, Y. J., and Hwang, H. J. (2009). Inhibitory effects of garlic and other spices on biogenic amine production in MyeolchiJeot, Korean salted and fermented anchovy product. Food Control 20, 449-454.

Malle, P., Valle, M., and Bouquelet, S. (1996). Assay of biogenic amines involved in fish decomposition. J. AOAC Int. 79, 43-49.

Marks, H., and Anderson, C. (2006). Rapid determination and confirmation of biogenic amines in tuna loin by gas chromatography/mass spectrometry using ethylchloroformate derivative. J. AOAC Int. 81, 1591-1599. 
Merson, M. H., Baine, W. B., Gangarosa, E. J., Swanson, R. C. (1974). Scombroid fish poisoning. outbreak traced to commercially canned tuna fish. J. Am. Med. Assoc. 228, 1268-1269.

Middlebrooks, B. L., Toom, P. M., Douglas, W. I., Harrison, R. E., and McDowell, S. (1988). Effects of storage time and temperature on the microflora and amine development in Spanish mackerel (Scomberomorus maculatus). J. Food Sci. 53, 1024-1029.

Mietz, J. L., and Karmas, E. (1978). Polyamine and histamine content of rockfish, salmon, lobster, and shrimp as an indicator of decomposition. J. AOAC Int. 61, 139-145.

Mietz, J. L., and Karmas, E. (1981). Biogenic amines as indicators of seafood freshness. Lebensm. Wiss. Technol. 14, 273-275.

Mohamed, R., Livia, S. S., Hassan, S., Soher, E. S., and Ahmed-Adel, E. B. (2009). Changes in free amino acids and biogenic amines of Egyptian salted-fermented fish (Feseekh) during ripening and storage. Food Chem. 115, 635-638.

Molinari, G., Montagnoli, G., Pellegrini, G., and Caroli, G. (1989). Hygiene and health importance of histamine as an unhealthy factor in several food products. Ann. Ig. 1, 637-646.

Morli, H., Cann, D. C., and Taylor, L. I. (1988). Histamine formation by luminous bacteria in mackerel stored at low temperatures. Nippon Suisan Gakkai Shi 54, 299-305.

Müller, G. J., Lamprecht, J. H., and Barnes, J. M. (1992). Scombroid poisoning: case series of 10 incidents involving 22 patients. S. Afr. Med. J. 81, 427-430.

Muñoz-Atienza, E., Landeta, G., de las Rivas, B., Gómez-Sala, B., Muñoz, R., Hernández, P. E., Cintas, L. M., and Herranz, C. (2011). Phenotypic and genetic evaluations of biogenic amine production by lactic acid bacteria isolated from fish and fish products. Int. J. Food Microbiol. 146, 212-216.

Naila, A., Flint, S., Fletcher, G., Bremer, P., and Meerdink, G. (2010). Control of biogenic amines in food - existing and emerging approaches. J. Food Sci. 75, R139-R150.

Naila, A., Flint, S., Fletcher, G. C., Bremer, P. J., and Meerdink, G. (2011). Biogenic amines and potential histamine - forming bacteria in rihaakuru (a cooked fish paste). Food Chem. 128, 479-484.

Olsen, S. J., MacKinnon, L. C., Goulding, J. S., Bean, N. H., and Slutsker, L. (2000). Surveillance for foodborne disease outbreaks, United States, 1993-1997. MMWR CDC Surveill. Summ. 49, 1-62.

Özogul, F., and Özogul, Y. (2006). Biogenic amine content and biogenic amine quality indices of sardines (Sardina pilchardus) stored in modified atmosphere packaging and vacuum packaging. Food Chem. 99, 574-578.

Özogul, F., Taylor, K. D. A., Quantick, P., and Özogul, Y. (2002). Changes in biogenic amines in herring stored under modified atmosphere and vacuum pack. J. Food Sci. 67, 2497-2501.

Paleologos, E. K., Savvaidis, I. N., and Kontominas, M. G. (2004). Biogenic amines formation and its relation to microbiological and sensory attributes in ice-stored whole, gutted and filleted Mediterranean sea bass (Dicentrarchus labrax). Food Microbiol. 21, 549-557.

Park, J. S., Lee, C. H., Kwon, E. Y., Lee, H. J., Kim, J. Y., and Kim, S. H. (2010). Monitoring the contents of biogenic amines in fish and fish products consumed in Korea. Food Control 21, 1219-1226.

Periago, M. J., Rodrigo, J., Ros, G., Rodríguez-Jerez, J. J., and Hernández-Herrero, M. (2003). Monitoring volatile and non volatile amines in dried and salted roes of tuna (Thunnus thynnus L.) during manufacture and storage. J. Food Prot. 66, 335-340.

Petäjä, E., Eerola, S., and Petäjä, P. (2000). Biogenic amines in coldsmoked fish fermented with lactic acid bacteria. Eur. Food Res. Technol. 210, 280-285.

Phuvasate, S., and Su, Y. C. (2010). Effects of electrolyzed oxidizing water and ice treatments on reducing histamine-producing bacteria on fish skin and food contact surface. Food Control 21, 286-291.

Pons-Sánchez-Cascado, S., VecianaNogués, M. T., Bover-Cid, S., Mariné-Font, A., and Vidal-Carou, M. C. (2005a). Volatile and biogenic amines, microbiological counts, and bacterial amino acid decarboxylase activity throughout the salt-ripening process of anchovies (Engraulis encrasicholus). J. Food Prot. 68, 1683-1689.

Pons-Sánchez-Cascado, S., VidalCarou, M. C., Mariné-Font, A., and Veciana-Nogués, M. T. (2005b). Influence of the freshness grade of raw fish on the formation of volatile and biogenic amines during the manufacture and storage of vinegar-marinated anchovies. J. Agric. Food Chem. 53, 8586-8592.

Rawles, D. D., Flick, G. J., and Martin, R. E. (1996). Biogenic amines in fish and shellfish. Adv. Food Nutr. Res. 39, 329-364.

Rossano, R., Mastrangelo, L., Ungaro, N., and Riccio, P. (2006). Influence of storage temperature and freezing time on histamine level in the European anchovy Engraulis encrasicholus (L., 1758): a study by capillary electrophoresis. J. Chromatogr. B Analyt. Technol. Biomed. Life Sci. 830, 161-164.

Rossi, S., Lee, C., Ellis, P. C., and Pivarnik, L. F. (2002). Biogenic amines formation in bigeye tuna steaks and whole skipjack tuna. $J$. Food Sci. 67, 2056-2060.

Sanchez-Guerrero, I. M., Vidal, J. B., and Escudero, A. I. (1997). Scombroid fish poisoning: a potentially life-threatening allergic-like reaction. J. Allergy Clin. Immunol. 100, 433-434.

Sato, M., Tao, Z. H., Shiozaki, K., Nakano, T., Yamaguchi, T., Kumagai, T., Yokoyama, T., Kanno, N. and Nagahisa, E. (2002). A rapid method or histamine analysis of seafoods by paper electrophoresis. ITE Lett. Batt. New Tech. Med. 3 , 501-503.

Sato, M., Tao, Z. H., Shiozaki, K. Nakano, T., Yamaguchi, T., Yokoyama, T., Anno, N., and Nagahisa, E. (2006). A simple and rapid method for the analysis of fish histamine by paper electrophoresis. Fish. Sci. 72, 889-892.

Scoging, A. C. (1998). Scombrotoxic (histamine) fish poisoning in the United Kingdom. Commun. Dis. Public Health 1, 204-205.

Shakila, R. J., Vasundhara, T. S., and Kumudavally, K. V. (2001). A comparison of the TLC-densitometry and HPLC method for the determination of biogenic amines in fish and fishery products. Food Chem. 75, 255-259.

Shakila, R. J., Vijayalakshmi, K., and Jeyasekaran, G. (2003). Changes in histamine and volatile amines in six commercially important species of fish of the Thoothukkudi coast of Tamil Nadu, India stored at ambient temperature. Food Chem. 82, 347-352.

Staruszkiewicz, W. F., Barnett, J. D., Rogers, P. L., Benner, R. A. Jr., Wong, L. L., and Cook, J. (2004). Effects of on-board and dockside handling on the formation of biogenic amines in mahi-mahi (Coryphaena hippurus), skipjack tuna (Katsuwonus pelamis), and yellowfin tuna
(Thunnus albacares). J. Food Prot.67, 134-141.

Stede, M., and Stockemer, J. (1981). Biogene amine in seefischen. Lebensm. Wiss. Technol. 19, 283-287.

Stratton, J. E., Hutkins, R. W., and Taylor, S. L. (1991). Biogenic amines in cheese and other fermented foods: a review. J. Food Prot. 54, 460-470.

Suzzi, G., and Gardini, F. (2003). Biogenic amines in dry fermented sausages: a review. Int. J. Food Microbiol. 88, 41-54.

Tahmouzi, S., Khaksar, R., and Ghasemlou, M. (2011). Development and validation of an HPLC-FLD method for rapid determination of histamine in skipjack tuna fish (Katsuwonus pelamis). Food Chem. 126, 756-761.

Tao, Z., Nakano, T., Yamaguchi, T., and Sato, M. (2002). Production and diffusion of histamine in the muscle of scombroid fishes. Fish. Sci. 68, 1394-1397.

Tao, Z., Sato, M., Han, Y., Tan, Z., Yamaguchi, T., and Nakano, T. (2011). A simple and rapid method for histamine analysis in fish and fishery products by TLC determination. Food Control 22, 1154-1157.

Tao, Z., Sato, M., Yamaguchi, T., and Nakano, T. (2009). Formation and diffusion mechanism of histamine in the muscle of tuna fish. Food Control 20, 923-926.

Taylor, S. L. (1986). Histamine food poisoning: toxicology and clinical aspects. Crit. Rev. Toxicol. 17, 91-128.

Thapa, N., Pal, J., and Tamang, J. P. (2006). Phenotypic identification and technological properties of lactic acid bacteria isolated from traditionally processed fish products of the Eastern Himalayas. Int. J. Food Sci. 107, 33-38.

Tsai, Y. H., Chang, S. C., Kung, H. F., Wei, C. I., and Hwang, D. F. (2005a). Histamine production by Enterobacter aerogenes in sailfish and milkfish at various storage temperatures. J. Food Prot. 68, 1690-1695.

Tsai, Y. H., Kung, H. F., Lee, T. M., Chen, H. C., Chou, S. S., Wei, C. I., and Hwang, D. F. (2005b). Determination of histamine in canned mackerel implicated in a food borne poisoning. Food Control 16, 579-585.

Tsai, Y. H., Kung, H. F., Lee, T. M., Lin, G. T., and Hwang, D. F. (2004) Histamine-related hygienic qualities and bacteria found in popular commercial scombroid fish 
fillets in Taiwan. J. Food Prot. 67, 407-412.

Tsai, Y. H., Lin, C. Y., Chien, L. T., Lee, T. M., Wei, C. I., and Hwang, D. F. (2006). Histamine contents of fermented fish products in Taiwan and isolation of histamineforming bacteria. Food Chem. 98, 64-70.

Veciana-Nogués, M. T., Mariné-Font, A., and Vidal-Carou, M. C. (1997a). Biogenic amines as hygienic quality indicators of tuna. relationships with microbial counts, ATP-related compounds, volatile amines, and organoleptic changes. J. Agric. Food Chem. 45, 2036-2041.

Veciana-Nogués, M. T., Mariné-Font, A., and Vidal-Carou, M. C. (1997b). Biogenic amines in fresh and canned tuna. J. Agric. Food Chem. 45, 4324-4328.

Veciana-Nogués, M. T., Mariné-Font, A., and Vidal-Carou, M. C. (1997c). Changes in biogenic amines during the storage of mediterranean anchovies immersed in oil. J. Agric. Food Chem. 45, 1385-1389.

Visciano, P., Campana, G., Annunziata, L., Vergara, A., and Ianieri, A. (2007). Effect of storage temperature on histamine formation in Sardina pilchardus and Engraulis encrasicolus after catch. J. Food Biochem. 31, 577-588.

Watanabe, S., Matsuo, K., Suzuki, Y., Tachibana, M., Tani, K., Koizumi, H., Matsumoto, K., and Kiba, N. (2007). Determination of histamine in fish sauce by photometric flow injection analysis with immobilized histamine oxidase reactor. Bunseki Kagaku 56, 1033-1036.

Yongsawatdigul, J., Choi, Y. J., and Udomporn, S. (2004). Biogenic amines formation in fish sauce prepared from fresh and temperatureabused Indian anchovy (Stolephorus indicus). Food Chem. Toxicol. 69, 312-319.
Zarei, M., Najafzadeh, H., Enayati, A., and Pashmforoush, M. (2011). Biogenic amines content of canned tuna fish marketed in Iran. American-Eurasian J. Toxicol. Sci. 3, 190-193.

Zhai, H., Yang, X., Li, L., Xia, G., Cen, J., Huang, H., and Hao, S. (2012). Biogenic amines in commercial fish and fish products sold in southern china. Food Control 25, 303-308.

Zhang, L. Y., and Sun, M. X. (2004) Determination of histamine and histidine by capillary zone electrophoresis with pre-column naphthalene-2,3-dicarboxaldehyde derivatization and fluorescence detection. J. Chromatogr. A 1040, 133-140.

Conflict of Interest Statement: The authors declare that the research was conducted in the absence of any commercial or financial relationships that could be construed as a potential conflict of interest.

Received: 05 March 2012; paper pending published: 26 March 2012; accepted: 09 May 2012; published online: 04 June 2012.

Citation: Visciano $P$, Schirone $M$, Tofalo $R$ and Suzzi G (2012) Biogenic amines in raw and processed seafood. Front. Microbio. 3:188. doi: 10.3389/fmicb.2012.00188

This article was submitted to Frontiers in Food Microbiology, a specialty of Frontiers in Microbiology.

Copyright (C) 2012 Visciano, Schirone, Tofalo and Suzzi. This is an openaccess article distributed under the terms of the Creative Commons Attribution Non Commercial License, which permits non-commercial use, distribution, and reproduction in other forums, provided the original authors and source are credited. 